\title{
Sponge spicules and radiolarians from the Olešná Member of the Klabava Formation (Ordovician, Prague Basin, Czech Republic)
}

\author{
MICHAL MERGL \& JAN DURŠPEK
}



\begin{abstract}
Abundant, morphologically moderately diverse, and well-preserved hexactinellid sponge spicules, mostly pentactines and hexactines, were collected from the lower Olešná Member of the Klabava Formation (Arenigian) of the Komárov area, Prague Basin. Demosponges, represented by lithistiid dendroclones and the large radiolarian genus Anacrusa, were identified in the acid-etched residue of (?) phosphatic clasts. The species Pyritonema feistmanteli is critically revised. Key words: Porifera, Hexactinellida, Lithistida, Radiolaria, Arenigian, Ordovician, Prague Basin, Bohemia.
\end{abstract}

MERGL, M. \& DURŠPEK, J. 2006. Sponge spicules and radiolarians from the Olešná Member of the Klabava Formation (Ordovician, Prague Basin, Czech Republic). Bulletin of Geosciences 81(1), 17-26 (7 figures, 1 table). Czech Geological Survey, Prague. ISSN 1214-1119. Typescript received May 25, 2005; accepted in revised form January 12, 2006; issued March 31, 2006.

Michal Mergl, University of West Bohemia, Department of Biology, Klatovská 51, 306 19, Plzeň, Czech Republic; mmergl@kbi.zcu.cz•Jan Duršpek, University of West Bohemia, Department of Biology, Klatovská 51, 306 19, Plzen̆, Czech Republic; jan.dur@email.cz.

Hexactinellid sponges are known in the geologic record from hexactine spicules that begin in the Late Proterozoic. This group flourished during the Middle Cambrian time. Despite a gradual decline from the Jurassic, about 120 extant genera are known (Krautter 2002).

Our knowledge of fossil hexactinellid sponges is largely derived from isolated spicules, mostly hexactines and pentactines; the finds of complete sponges are rare (e.g., Pickett \& Plusquellec 1998). However, the continuing search for disarticulated sponge spicules improves our knowledge of the evolution and taxonomy of the group. Remarkably shaped spicules from the Cambrian and Ordovician that have been described during the past ten years (e.g., Webby \& Trotter 1993, Dong \& Knoll 1996, Zhang $\&$ Pratt 2000) indicate that even isolated spicules can bring new insights to the evolutionary history of the hexactinellid sponges.

In the Palaeozoic succession of Central Bohemia, the disarticulated spicules of hexactinellid sponges are exceedingly abundant in the reddish cherts of the Milina Formation (Upper Tremadocian), but they are also known from the Jince Formation of the Middle Cambrian, from the Třenice Formation (Tremadocian), and from younger Ordovician, Silurian, and Devonian strata. However, these finds have only been described in brief reports (e.g., Bouček 1936, Havlíček \& Šnajdr 1951).
Among other fossils, spicules are common in the reddish siltstones (i.e., Olešná Member) and the rewashed tuffs (i.e., Ejpovice Member) of the Klabava Formation (Arenigian). These spicules have been briefly described by Počta (1898) in a short paper devoted to sponges of the "Paleozoic basin" of Central Bohemia. However, the stratigraphical and locality data given by that author are inadequate by modern standards and somewhat in contradiction with the modern stratigraphical division of the Ordovician of the area. Therefore, in addition to a description and re-evaluation of the species Pyritonema feistmanteli, other data presented by Počta (1898) are discussed here.

\section{Locality and stratigraphy}

New material has been collected from the SW part of the Prague Basin. The Olešná Member of the Klabava Formation is a $20-30 \mathrm{~m}$ thick, lithologically uniform sequence of red-brown siltstones and fine-grained greywackes in this area. The unique fossil material from this unit has been collected from the low hill west of the village Těně, near the field road from Těně to Strašice (Fig. 1). This locality (Těně, west) has been fully described by Mergl (1986), including the detailed lithological column of the Mílina-Klabava 




Figure 1. A - schematic map showing the location of the Bohemian Massif, the Czech Republic and the Prague Basin. $\bullet$ B - geographic distribution of the Ordovician strata in the Prague Basin with the main sponge-bearing localities in the Olešná Member of the Klabava Formation. • C - Lithology of Mílina-Klabava formations boundary interval at the Těně locality (west), with marked level that contains large monaxons (M) and the bed with spicule-bearing phosphatic clasts (S). Unit B bears the stratigraphically significant lingulate brachiopod Thysanotos siluricus (Eichwald, 1840). 1 - chert, 2 - greywacke, 3 - siltstone.

formations boundary interval. Sponge spicules are known from three levels in this locality.

The spicules from reddish cherts of the Mílina Formation (unit A) are poorly preserved and have not been studied. They are not discussed in the present paper. The lower part of unit E (according to Mergl 1986), about $0.5 \mathrm{~m}$ above the formation boundary, yielded abundant large monaxons. Unit $\mathrm{H}$, about $3 \mathrm{~m}$ higher, is characterized by (?) phosphatic clasts intercalated inside a greywacke bed. The greywacke bed is known as being an excellent stratigraphic marker in the area between Komárov and Strašice. The clasts yielded a remarkably rich fauna (of more than 17 species) of linguliform brachiopods (Mergl 2002) and very numerous sponge spicules. The interpretation of the exact age of the fauna is difficult, because all index microfossils and graptolites are missing apart from the paraconodont Westergaardodina Müller, 1959. However, the presence of the significant lingulate brachiopod Thysanotos siluricus (Eichwald, 1840) approximately 5-6 m below the unit $\mathrm{H}$, and the composition of the microbrachiopod assemblage, indicate that the measured succession is latest Tremadocian or early Arenigian in age (approximate equivalent of $D$. deltifer or P. proteus Biozones).

Stratigraphically higher beds of the Olešná Member are characterized by a deeper red color of the siltstones. Fossil-rich material from these beds has been collected in a road cut in the field between Těně and Strašice (Strašice, east), and in rock debris at the top of a low hill near the cemetery and church of St. Vojtěch east of Strašice (Strašice, St. Vojtěch). Additional sponge material from other localities of the Olešná Member in the Komárov area, including specimens collected by C. Klouček between the years of 1910-1920, has been revised. However, the stratigraphical data are less precise and only some specimens could be located more exactly. The list and names of localities were given by Mergl (2002).

\section{Material and methods}

Isolated sponge spicules were etched from (?) phosphatic clasts (1-2 cm sized) by dilute (about 10 percent) hydrochloric acid, then repeatedly washed and collected under a binocular lens. Sieving was avoided in the interest of preventing breakage of fragile spicules. In total, several thousand, mostly slightly broken, spicules were studied. Other spicules are preserved as external moulds in siltstone, often with very fine details preserved.

The type specimens of Počta (NM L 27310, NM L 27326, NM L 27327, NM L 27415, NM L 27416) and the specimens from the collection of C. Klouček (ČD 40, С̌D 62, NM L 38017) are stored in the palaeontological collection of the National Museum, Prague (NM L); the newly collected material is stored in the palaeontological collections of the University of West Bohemia, Plzeň (PCZCU). 


\section{Systematic palaeontology}

Phylum Porifera Grant, 1836

Class Hexactinellida Sollas, 1875

Remarks. - Hexactinellid sponges are represented by various types of spicules in the residue and siltstones (Table 1). They cannot be referred to any specific species because the actual arrangement of spicules and shape of the sponge body are unknown. Rare clusters of spicules that indicate their original position in a body wall (Figs 5A, B) provide limited information concerning their biological identity.

From the different shapes of spicules and their restriction to discrete beds, it can be estimated that there are at least three different species. They are separately described, but the formal naming of them is avoided.

Table 1. Number of spicules from the residue from unit $\mathrm{H}$ in the Těně locality (west); the distinct prevalence of pentactines is evident (total 1936 spicules)

\begin{tabular}{lcc}
\hline Type of spicule & No. of individuals & Percentage \\
\hline Monaxons & 67 & 3.5 \\
Pentactines & 1472 & 76.0 \\
Hexactines & 332 & 17.2 \\
Dendroclones & 65 & 3.3 \\
\hline
\end{tabular}

Order uncertain

Family uncertain

Gen. et sp. indet. A

Figures 3D, F-K, M, O, P, R-V, 4A-E, 5A-C

1898 Pyritonema Feistmanteli Počta; Počta, p. 6, figs 13-23.

Material. - Several hundred specimens and one cluster of 22 pentactines in almost original position (? fragment of wall of sponge).

Description. - Of the several hundred spicules coming from the residue, pinnate pentactines are the most common. They are about 1-2 mm long, with rays about $100 \mu \mathrm{m}$ in basal diameter. There is great variety of spicule shape, but almost all could be derived from a spicule with long pinnate central ray and four smooth lateral rays inclined at about $100^{\circ}$ to the axis of the central ray (Fig. 2A). The central ray is pinnate, with small spines over the entire surface, except for a short collar near the base, which is smooth and slightly narrower than the rest of the ray. The central ray is straight, weakly but sometimes even strongly curved; its length is remarkably variable and in some spicules is very short (Fig. 2C). Lateral rays rapidly taper with smooth

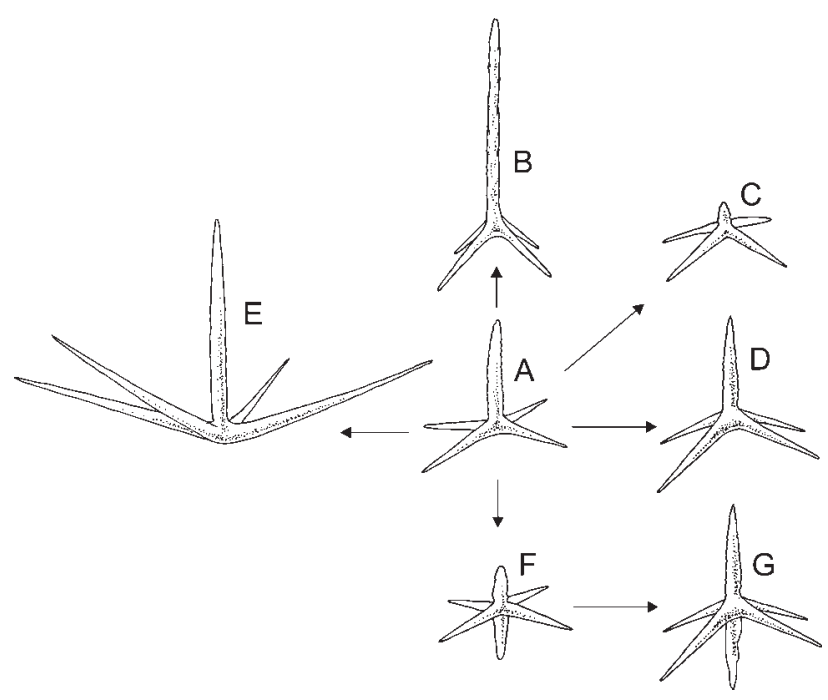

Figure 2. Various types of pentactines and hexactines from the Olešná Member. $\bullet$ A - pinnate pentactine with $100^{\circ}$ angle of lateral rays. • B pinnate pentactine with long central ray and inclined (more than $100^{\circ}$ angle) lateral rays. $\cdot \mathrm{C}$ - pinnate pentactine with short central ray and inclined lateral rays. $\bullet \mathrm{D}-$ pinnate pentactine with inclined lateral rays. $\bullet \mathrm{E}-$ large pinnate pentactine with reversely (less than $90^{\circ}$ angle) inclined lateral rays. $\bullet \mathrm{F}$ - pinnate hexactine with short central ray and $100^{\circ}$ angle of lateral rays. $\bullet \mathrm{G}-$ pinnate hexactine with inclined lateral rays. Further explanation in the text.

surfaces. The incline of lateral rays is much higher, being to $140-150^{\circ}$ in all specimens (Figs 2C, D). A derived type of pentactine (Figs 2B, 3G, H, O) has a very long central ray, which is covered by low, spirally arranged, elongate tubercles (Figs 3I, J); these latter pentactines may belong to another species, as may be inferred from different external structure of the central ray.

Large pentactines in the original group (Figs 5A, B) have lateral rays inclined at angles less than $90^{\circ}$; angles of $70-80^{\circ}$ are common (Fig. 2E). These large pentactines have rather short central rays and are probably associated with the dermal surface of a sponge; smaller pinnate pentactines and hexactines may have been located deeper in the body of a sponge or supported the surface between larger pentactines.

Hexactines are much rarer. They have a pinnate central ray. The opposite ray is smooth, shorter, and narrower than the lateral rays (Figs 2F, G, 3R, V).

Discussion. - These pentactines and hexactines are the commonest elements among the remains of sponges in the Olešná Member of the Klabava Formation. The poorly preserved small spicules associated with the so-called sphaerasters of Pyritonema feistmanteli fall within the variation range of the described spicules (Počta 1898). Very similar pentactines and hexactines are known elsewhere from the Middle Cambrian (Dong \& Knoll 1996) and Ordovician (Webby \& Trotter 1993); their taxonomic significance is unclear. 
Feistmantel (1884) was the first worker to note the presence of sponge spicules in the Lower Ordovician of the Prague Basin. Počta (1898) formally described and illustrated three species of sponges from the Lower Ordovician of the Prague Basin, apart of several other species from higher stratigraphical levels. He named these new species Pyritonema barrandei, Pyritonema feistmanteli, and Protospongia novaki, all from the Krušná Hora Beds. These species names were commonly used in subsequent papers (e.g., Havlíček \& Vaněk 1966) and in the lists of fossils of the Mílina and Klabava formations. However, only Pyritonema feistmanteli is described by Počta (1898) from a stratigraphic level of comparable age with the new material. The species Pyritonema barrandei and Protospongia novaki have been collected from stratigraphically younger tuffaceous shales of the upper part of the Klabava Formation.

In conclusion, none of Počta's (1898) surviving type material was derived from the Třenice and Mílina formations (Tremadocian), and his stratigraphical attribution of spicules-bearing rocks to the Krušná Hora Beds is mostly erroneous. All his figured specimens were collected in younger rocks of the Klabava Formation (Arenigian). Data concerning the spicules in the Mílina Formation Počta (1898) were adopted from the earlier paper of Feistmantel (1884).

Occurrence. - Unit H (Mergl 1986) and a stratigraphically higher succession of the Olešná Member, Klabava Formation; abundant in many localities: Těně (west, village), Cerhovice (Cerhovská Hora hill), Horní Kvaň (field), Olešná (quarry), Strašice (east, field near St. Vojtěch), and Zaječov (Hrbek, Svatá Dobrotivá).

\section{Gen. et sp. indet. B}

Figures 3A, B, E, L, N, Q

Material. - Several isolated spicules.

Description. - The hexactines included here are small, with all rays rapidly tapering and having smooth surfaces. One short thick monaxon with acute ends could belong to the same species. Small monaxons with stick-like terminations always occur with their opposite ends broken.
Discussion. - These hexactines and monaxons probably belong to different species than the pentactines and hexactines with a pinnate central ray. This is suggested by presence of a smooth central ray and more rapidly tapering rays. The biological affinity of the small monaxons with stick-like terminations is unclear.

Occurrence. - Unit H (Mergl 1986), Olešná Member, Klabava Formation; rare in locality Těně (west).

\section{Gen. et sp. indet. C}

Figures 5D, E

Material. - About a hundred specimens, mostly preserved as external moulds.

Description. - Monaxons are straight, $300 \mu \mathrm{m}$ in diameter, to $15 \mathrm{~mm}$ long (originally probably longer) of uniform shape. Despite numerous available specimens, no tapering ends are known; all spicules are truncated in the matrix. There is a poorly preserved (by mineral infilling) axial canal in some spicules.

Discussion. - These monaxons are common in a red-brown siltstone bed $30-40 \mathrm{~cm}$ above the Mílina-Klabava formations boundary. This bed is a good local stratigraphical marker in the area between Strašice and Komárov. Spicules are exceedingly abundant in this bed, and are associated with the broken shells of lingulate brachiopods. The monaxons are not associated with other spicules; it therefore seems probable that they originated from species other than those with hexactines and pentactines, which are abundant higher in the succession. Explaning this bed as a residual association of root spicules after the destruction of exposed higher parts of sponges seems attractive. Although the generic name Pyritonema McCoy, 1850 has been interpreted as a bunch of root spicules and could be applied to these monaxons, a formal naming of the spicules is avoided.

Occurrence. - Lower part of unit E (Mergl 1986), Olešná Member, Klabava Formation; abundant in localities Těně (west), Mílina (quarry), Olešná (quarry), and Zaječov (Hrbek).

Figure 3. Hexactinellid (A, B, D-V), and lithistid (C) sponge spicules. All specimens come from the Těně (west) locality; Olešná Member of the Klabava Formation. $\bullet$ Gen. et sp. indet. A. G, F- pinnate pentactine with curved central ray in two views, PCZCU 1523 , both $\times 45$. G - pinnate pentactine, PCZCU $1525, \times 35 . \bullet \mathrm{H}-$ pinnate pentactine, PCZCU $1526, \times 65 . \bullet \mathrm{I}, \mathrm{J}-$ pinnate broken central ray of pentactine, PCZCU $1527, \times 75, \times 40 . \bullet \mathrm{K}-$ pinnate pentactine, upper side, PCZCU $1529, \times 70 . \bullet \mathrm{M}-$ pinnate pentactine, upper side, PCZCU $1535, \times 55 . \bullet \mathrm{O}-$ Pinnate pentactine, upper side, PCZCU 1528 , $\times 65 . \bullet \mathrm{P}$ - pinnate pentactine, upper side, PCZCU $1531, \times 1531 . \bullet \mathrm{R}$ - pinnate hexactine, $\mathrm{PCZCU} 1538, \times 95 . \bullet \mathrm{S}-$ pinnate pentactine, lower side, $\mathrm{PCZCU}$ $1532, \times 65 . \bullet \mathrm{T}-$ pinnate pentactine, lower side, PCZCU $1530 . \bullet \mathrm{U}-$ pinnate pentactine, lower side, PCZCU 1534 . $\bullet \mathrm{V}-$ small pinnate hexactine, PCZCU 1539. • Gen. et sp. indet B. A, B - monaxons with stick-like terminations, PCZCU 1520 , PCZCU 1521 , both $\times 70$. $\bullet$ E - monaxon, PCZCU $1524, \times 70$. $\bullet$ $\mathrm{L}-$ small hexactine, PCZCU $1556, \times 65 . \bullet \mathrm{N}-$ hexactine, PCZCU $1536, \times 65 . \bullet \mathrm{Q}-$ hexactine, PCZCU $1537, \times 95$. $\bullet$ Gen. et sp. indet. D. C - monaxon with blunt end, PCZCU $1522, \times 40$. 
Michal Mergl \& Jan Duršpek • Sponge spicules and radiolarians from the Olešná Member

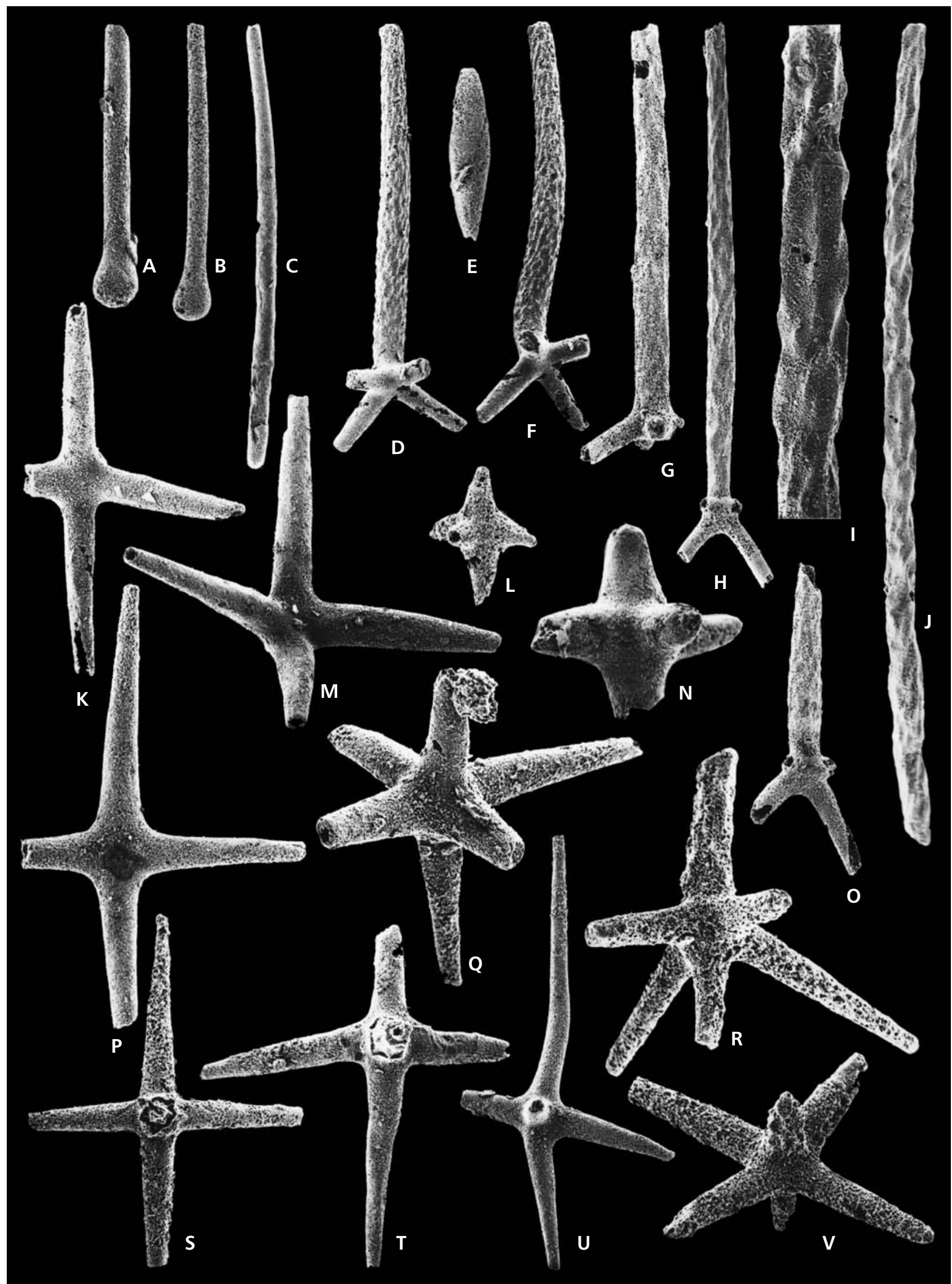




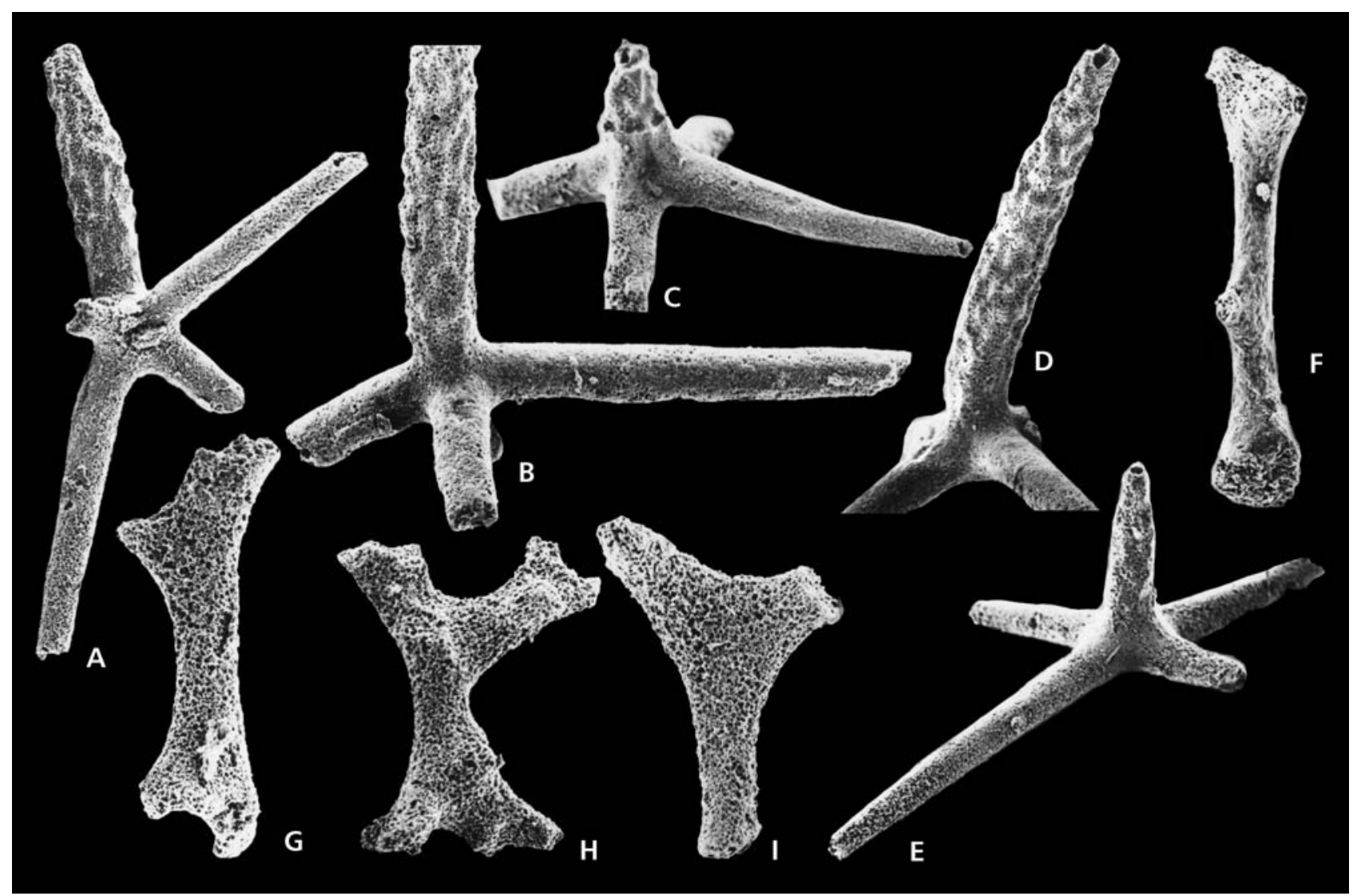

Figure 4. Hexactinellid (A-E), and lithistid (F-I) sponge spicules. Specimens come from Těně (west) (A-I) locality; Olešná Member of the Klabava Formation. $\bullet$ Gen. et sp. indet. A. A - pinnate pentactine, PCZCU 1540, $\times 80$. $\bullet$ B, D - pinnate pentactine, detail of central ray, PCZCU 1541 , both $\times 80$. $\bullet$ $\mathrm{C}$ - pinnate pentactine with short central ray, PCZCU $1530, \times 65$. $\bullet$ E - pinnate pentactine, PCZCU $1542, \times 65$. $\bullet$ Gen. et sp. indet. D. F-I - lithistid dendroclones, PCZCU 1543, PCZCU 1544, PCZCU 1545, PCZCU 1546, all × 125.

Class Demospongia Sollas, 1875

Order Lithistida Schmidt, 1870

Gen. et sp. indet. D

Figures 3C, 4F-I

Material. - Seventy spicules.

Description. - X-shaped dendroclones are rare and mostly incomplete in the residues. They are most likely derived from one lithistid species. Their lengths are approximately 400-500 $\mu \mathrm{m}$ (based on fragments). The moderate variability of $\mathrm{X}$-shaped dendroclones is evident mainly in the lengths of the shaft. The shaft is generally short and smooth, cca 60-70 $\mu \mathrm{m}$ thick. Zygomes are poorly branching. A weakly curved smooth style with a blunt end (Fig. 3C) could belong to a lithistid sponge.

Discussion. - Dendroclones are known from the Middle Cambrian (Kruse 1990, 1996), and are common types of spicules in anthaspidellid sponges up to the Carboniferous (Rigby et al. 1970). Dendroclones from the Middle Cambrian of Australia (Zhang \& Pratt 2000) have more complex zygomes than the dendroclones from Bohemia. The dendroclones of anthaspidellids described by Freitas (1991) from the Ludlow of Canada have more complex zygomes and shorter shafts than those possessed by our dendroclones.

Anthaspidellids are common in Ordovician reefs and reef-like habitats, being widespread in North America (Bassler 1941) and in the Middle and Upper Ordovician of Baltica (Kempen 1978).

Anthaspidelid sponges have never been reported in the Ordovician of the Prague Basin. The high rarity of dendroclones among spicules in the residue indicates that lithistid sponges were uncommon in sponge associations in the early Ordovician in the Prague Basin.

Occurrence. - Unit H (Mergl 1986), Olešná Member, Klabava Formation; rare in locality Těně (west). 

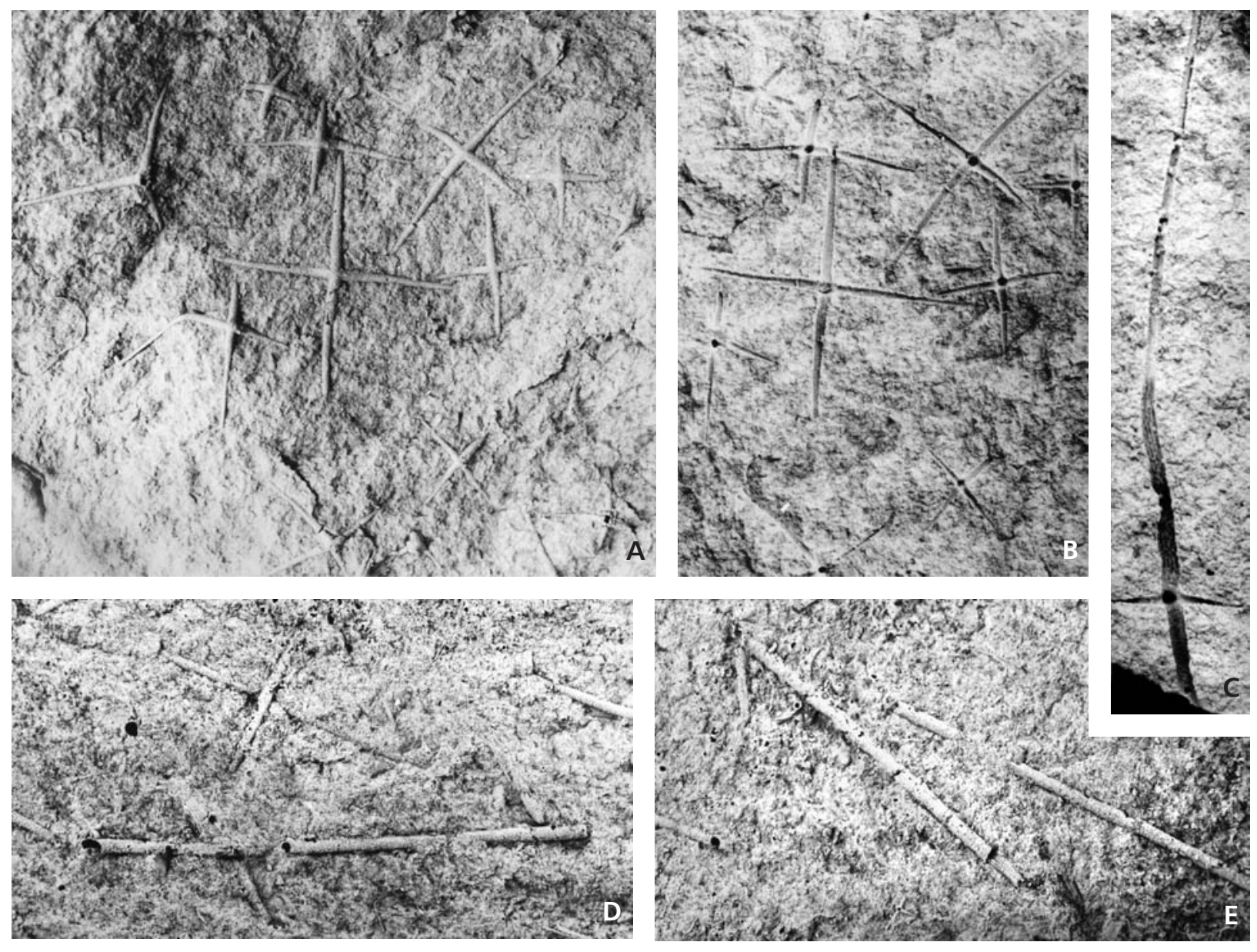

Figure 5. Hexactinellid sponge spicules. Specimens come from Strašice (east) (A-C), and Zaječov (Svatá Dobrotivá) (D, E) localities; Olešná Member of the Klabava Formation. $\bullet$ Gen. et sp. indet. A. A, B - natural group of large dermal (?) pentactines, latex cast of upper side (A) and external moulds showing central rays, PCZCU 1547 , both $\times 9$. $\bullet$ C - isolated large hexactine with very long pinnate central ray and very short lateral rays, external mould, PCZCU 1548, ×9. • Gen. et sp. indet. C. D, E - monaxons, latex casts of external moulds, both NM L 38017, both $\times 5$.

Class Actinopoda Calkins, 1909

Subclass Radiolaria Müller, 1858

Order uncertain

Family Anakrusidae Nazarov, 1977

\section{Genus Anakrusa Nazarov, 1977}

Type species. - Anakrusa myriacantha Nazarov, 1977; Middle Ordovician, Kazakhstan.

\section{Anakrusa feistmanteli (Počta, 1898)}

Figures 6A-I, 7A-C

1898 Pyritonema Feistmanteli Počta; Počta, p. 6, figs 11, 12.

Lectotype. - The specimen figured by Počta (1898) is here designated as NM L 27416a on fig. 11, left top. It is preserved as an external mould in red-brown shale, refigured here on Fig. 7C, right bottom.
Paralectotypes. - Seven specimens (NM L 27416b-h), figured by Počta (1898) on fig. 11, bottom, preserved as external mould in red-brown shale.

Type horizon. - Klabava Formation, Olešná Member, exact stratigraphical level unknown.

Type locality. - Barrandian, Zaječov (Svatá Dobrotivá area in original paper), exact locality unknown.

Material. - Apart from the type specimens, fifty specimens are preserved as external moulds in red-brown shale and five occur as isolated specimens.

Description. - Skeleton is globular, somewhat depressed at the poles, 520-650 $\mu \mathrm{m}$ in diameter (without spines). The maximum diameter with spines is $1350 \mu \mathrm{m}$. The wall is perforated by tubular long spines of uniform length (cca $250-350 \mu \mathrm{m}$ ) and diameter (cca 25 to $35 \mu \mathrm{m}$ ). The spines are regularly arranged in oblique rows. 


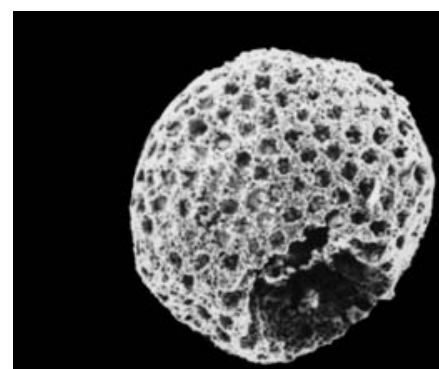

A
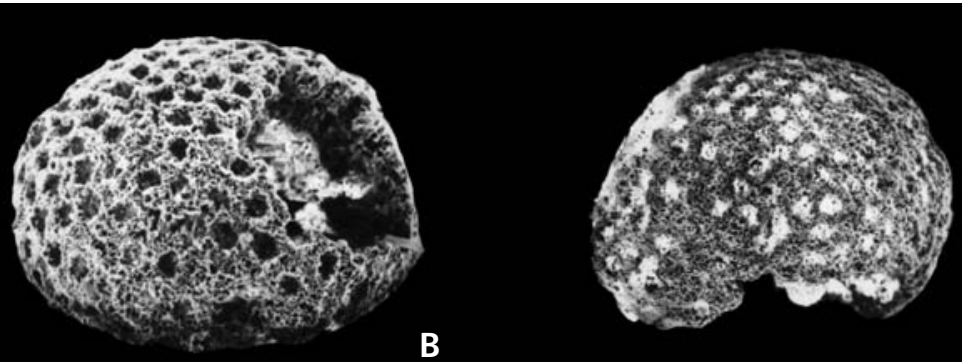

D

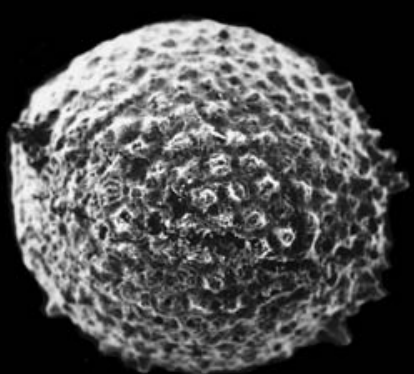

E

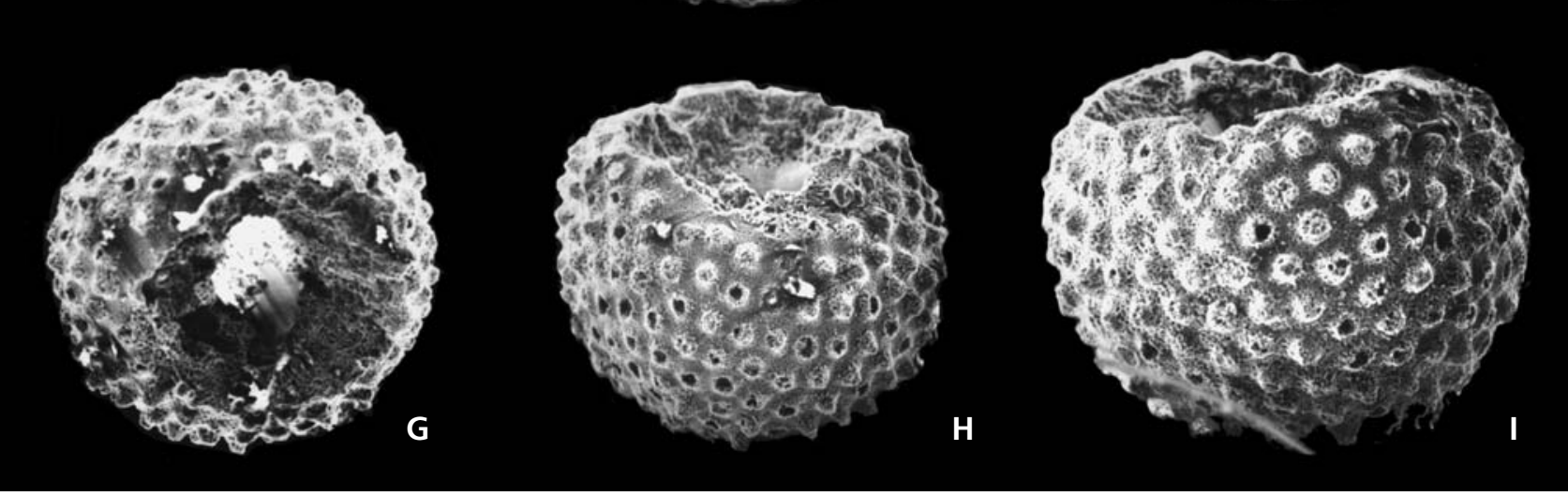

Figure 6. Anakrusa feistmanteli (Počta, 1898). Specimens come from Těně (west) locality; Olešná Member of the Klabava Formation. • A - specimen with broken spines, PCZCU 1550, × 75. • B - incomplete specimen PCZCU 1552, × 110 • C - incomplete specimen, PCZCU 1551, $\times 75$. $・$ D - complete specimen with preserved spines, PCZCU $1553, \times 75$. $\bullet$ E - complete specimen without spines, PCZCU $1554, \times 50 \cdot \bullet \mathrm{F}-$ complete specimen with eroded polar part, PCZCU $1555, \times 50 . \bullet \mathrm{G}-\mathrm{I}-$ almost complete specimen with broken spines showing regular arrangement of spines, PCZCU $1556, \times 85, \times 85, \times 100$

Discussion. - Počta (1898) described the new species of hexactinellid sponge under the name Pyritonema feistmanteli Počta. He described and figured various isolated spicules (monaxons, hexactines, and pentactines), but did not select any type specimen. Počta concluded that the main character of $P$. feistmanteli that distinguishes this species from others of the same genus is that it is a special type of sphaeraster. Počta concluded that the sphaeraster is hollow, with numerous hollow, radially arranged, fine spines on the external surface. He figured a slab with a natural group of these sphaerasters (fig. 11) and illustrated one specimen (fig. 12). While natural groups are readily identifiable among Počta's type material, the specimen illustrated on fig. 12 is dubious. Therefore, a lectotype has been selected from the original group of "sphaerasters" (Počta 1848, fig. 11; Fig. 7C, right bottom herein), despite the recommendation of the ICZN as explained below.
These globular bodies, the "sphaerasters" of Počta (1898), are almost identical to siliceous microfossils referred to the radiolarian genus Anakrusa Nazarov, 1977. The type specimen of Pyritonema feistmanteli Počta has been selected from Počta's original material, and is interpreted as Radiolaria incertae sedis, previously misinterpreted as a sphaeraster of Pyritonema. Consequently, the associated pentactine spicules described by Počta (1898) remain unnamed. These isolated spicules are identical to the currently described hexactines and pentactines from the Olešná Member (Gen. et sp. A), but because their real biological affinity is unclear no new name is proposed.

Anakrusa feistmanteli is stratigraphically the earliest known species of the genus. The earliest finds are known from unit $\mathrm{H}$, some $3.5 \mathrm{~m}$ above the boundary with the underlying Mílina Formation. The Mílina Formation is considered to be of late Tremadocian age (Mergl 1984). 
The associated fauna of organophosphatic brachiopods indicates a latest Tremadocian to early Arenigian age for the earliest bed with Anakrusa feistmanteli. The species is very rare in this stratigraphical level. The more abundant occurrence of A. feistmanteli begins about 10-15 m higher in the Olešná Member in the Strašice area. This higher level is distinguished by a different, brighter reddish color of the siltstones and by abundant large hexactinellid spicules. Outside the Olešná Member, the genus Anakrusa is reported only from the Bestamak Formation (upper Llanvirn-lower Caradoc) of Kazakhstan (Nazarov 1977, Nazarov \& Popov 1980). The type species A. myriacantha Nazarov, 1977 is similarly globular, but its spines are much shorter than those of $A$. feistmanteli. The species A. conspersa from Kazakhstan has distinctly conical hollow spines of variable lengths. The second anakrusiid genus, Auliela Nazarov, 1977, differs by having a smaller skeleton, but its longer tubular spines are more similar to A. feistmanteli than to other anakrusiids.

Anakrusa feistmanteli is the abundant species in platy siltstones of the Olešná Member. It is commonly preserved in natural groups of several specimens; groups of three to fifteen individuals are quite common. These groups are associated with isolated spicules of hexactinellid sponges. Anakrusiids are preserved as external moulds retaining the finest details. The anakrusiids are absent in rocks without spicules. The absence of Anakrusa in beds without spicules may have been original, or a result of the early diagenetic dissolution of the siliceous skeletal material. The beds containing higher contents of biogenic (?) silica were more favourable for the preservation of sponge spicules and delicate radiolarian shells. It is worth noting that one anakrusiid specimen has been found in a cluster of hexactinellid sponges in the oolitic haematite bed in the upper part of the Klabava Formation.

The abundant preservation of specimens in clusters indicates that they represent original groups, probably attached to the same soft substrate (or? inside a soft tissue). The benthic life mode for the genus Anakrusa can be inferred from these clusters. However, the benthic mode is uncommon for radiolarians, and the large size and unusual morphology do not characterise these protozoans. It is possible that Anacrusa is not a radiolarian but a strange hexactinellid spicule, as has been observed in other supposed radiolarians (Konyrium Nazarov \& Popov, 1976; see Dong \& Knoll 1996). If this is the case, the original opinion of Počta (1898) would be correct, and the name Anacrusa feistmanteli could be applied to pectactines and hexactines associated with the "sphaerasters". Because the actual biological affinity of Anacrusa needs further study, the lectotype is selected from "sphaerasters" and not from pentactines or hexactines; after all, Anacrusa could be a valid taxon of the Phylum Porifera.
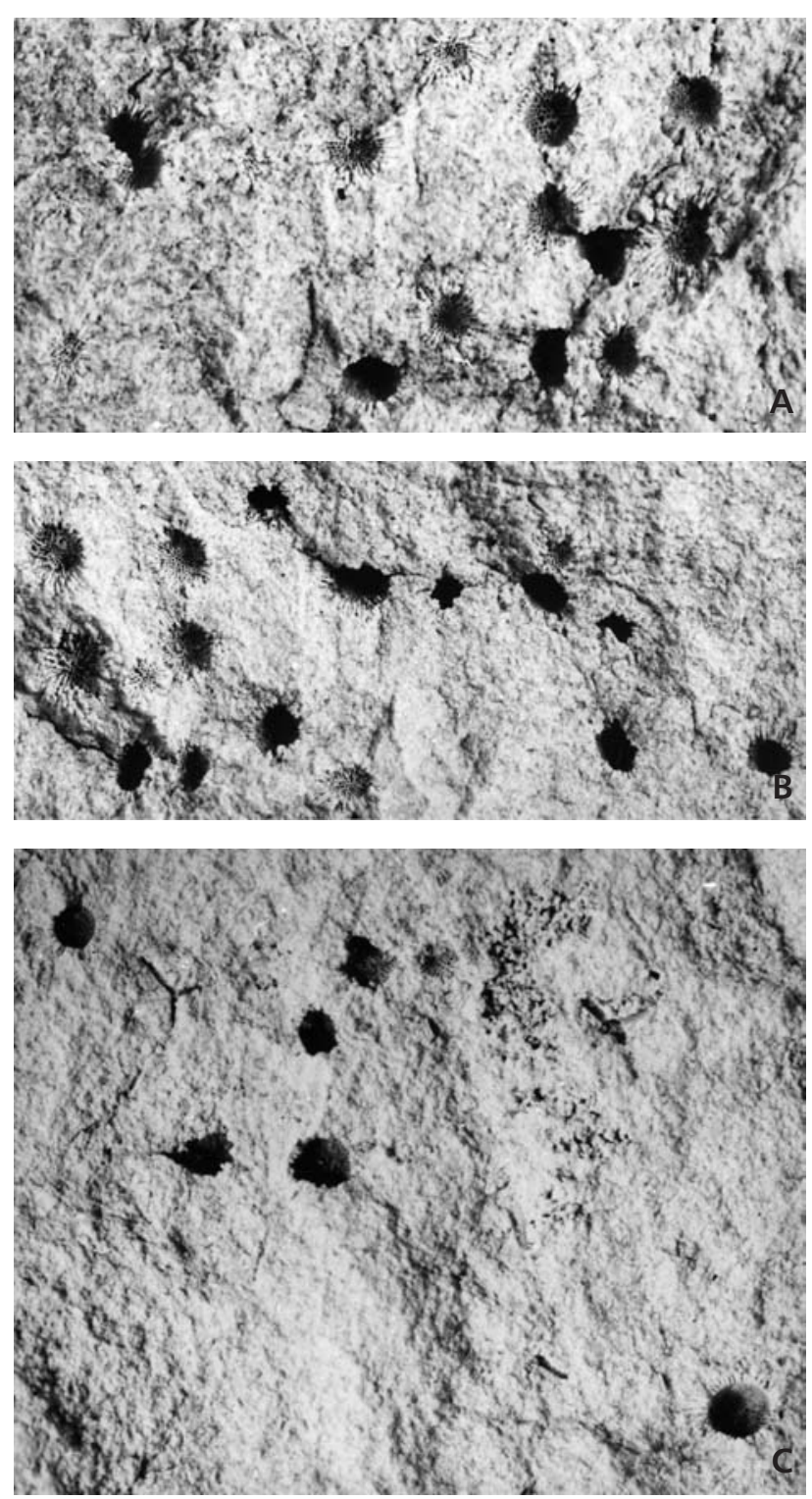

Figure 7. Anakrusa feistmanteli (Počta, 1898). Specimens come from Strašice (field near St. Vojtěch) (A, B), and Zaječov (Svatá Dobrotivá) (C) localities; Olešná Member of the Klabava Formation. • A, B - slab with 17 external moulds of radiolarian and their counterparts, PCZCU 1549, $\times 9$. • $\mathrm{C}$ - slab with seven external moulds of radiolarian, type specimens of Počta (1898); the lectotype is the specimen in right bottom, NM L 27415, $\times 9$.

Occurrence. - Unit H (Mergl 1986) and stratigraphically higher succession of the Olešná Member, Klabava Formation; rare in Těně (west) but abundant in the Strašice (east, field near St. Vojtěch) localities.

\section{Conclusions}

New findings of siliceous spicules provide the first evidence of the presence of lithistid sponges in the early Ordovician of the Prague Basin. Spicules of the of siliceous 
sponges show remarkable variation in spicule shapes, but indicate only a moderate diversity of spicule types, with dominant pinnate pentactines and much more rare monaxons and hexactines. The presence of three species of hexactinellid sponges is suggested by the fossil spicule associations. The species Pyritonema feistmanteli, formerly referred to sponges by Počta (1898), is referred here to the possible radiolarian genus Anakrusa. It is the earliest representative of this genus yet known.

\section{Acknowledgements}

This research was supported by the Grant Agency of the Czech Republic grant 205/03/0670 "Fauna and Stratigraphy of the Tremadocian in Bohemia". It is a contribution to IGCP Project 503 "Early Palaeozoic Palaeogeography and Palaeoclimate". The authors would like to thank the reviewers, J.K. Rigby and P. Kraft for their careful work.

\section{References}

BASSLER, R.S. 1941. The Nevada early Ordovician (Pogonip) sponge fauna. Proceedings of the United States National Museum 91(3126), 91-102.

BOUČEK, B. 1936. O planktonu českého silurského moře. Př́roda 29(5), 1-5.

Dong, X. \& Knoll, A.H. 1996. Middle and Late Cambrian sponge spicules from Hunan, China. Journal of Paleontology $70(2), 173-184$

FeISTMANTEL, K. 1884. Spongienreste aus silurischen Schichten von Böhmen. Sitzungsberichte der Königlichen Böhmischen Gesellschaft der Wissenchaft, 1-7.

Freitas, T.A. DE 1991. Ludlow (Silurian) lithistid and hexactinellid sponges, Cape Phillips Formation, Canadian Arctic. Canadian Journal of Earth Sciences 28, 2042-2061.

HAVLÍČEK, V. \& ŠNAJDR, M. 1951. Kambrium a ordovik v Brdských Hřebenech a na Jinecku. Sborník Ústředního ústavu geologického, Oddíl geologický 18, 145-276.

HAVLÍČEK, V. \& VANĚK, J. 1966. The biostratigraphy of the Ordovician of Bohemia. Sborník geologických věd, Paleontologie 8, 7-69.
KemPEN, T.M.G. VAN 1978. Anthaspidellid sponges from the Early Paleozoic of Europe and Australia. Neues Jahrbuch für Geologie und Paläontologie, Abhandlungen 156(3), 305-337.

KrautTer, M. 2002. Fossil Hexactinellida: An Overview, 1211-1223. In HoOPER, J.N.A. \& SOEST, R.W.M. vaN (eds) Systema Porifera: A Guide to the Classification of Sponges. Kluwer Academic-Plenum Publishers, New York.

KRUSE, P.D. 1990. Cambrian palaeontology of the Daly Basin. Northern Territory Geological Survey, Report 7, 1-58.

KRUSE, P.D. 1996. Update on the northern Australian Cambrian sponges Rankenella, Jawonya and Wagima. Alcheringa 20, 161-178.

Mergl, M. 1984. Fauna of the Upper Tremadocian of central Bohemia. Sborník geologických věd, Paleontologie 26, 9-46.

Mergl, M. 1986. The Lower Ordovician (Tremadoc-Arenig) Leptembolon Community in the Komárov area (SW part of the Prague Basin; Bohemia). Folia Musei rerum naturalium Bohemiae occidentalis, Geologica 24, 1-34.

MerGL, M. 2002. Linguliformean and craniiformean brachiopods of the Ordovician (Třenice to Dobrotivá formations) of the Barrandian, Bohemia. Acta Musei nationalis Pragae, Series B 58(1-2), 1-82.

NAZAROV, B.B. 1977. Novoje semejstvo radiolarij iz ordovika Kazakhstana. Paleontologitscheskij zhurnal 19(1), 35-41.

NAZAROV, B.B. \& POPOV, L.E. 1980. Stratigrafija i fauna kremnisto-karbonatnych tolstsch ordovika Kazachstana [Stratigraphy and fauna of Ordovician siliceous-carbonate deposits of Kazakhstan]. Trudy AN SSSR 331, 1-191.

Pickett, J. \& Plusquellec, Y. 1998. Eponges siliceuses du Dévonien supérieur de la Rade de Brest (France). Geobios 31(6), 715-723.

POČTA, F. 1898. O zbytcích hub z české pánve paleozoické. Rozpravy České akademie císaře Františka Josefa pro vědy, slovesnost a umění, Třída II 7, 24.

Rigby, J.K., Chamberlain, C.K. \& Black, B.A. 1970. Mississippian and Pennsylvanian sponges from the Ouachita Mountains of Oklahoma. Journal of Paleontology 44, 816-832.

Webiy, B.D \& Trotter, J. 1993. Ordovician sponge spicules from New South Wales, Australia. Journal of Paleontology 67(1), 28-41.

Zhang, X.G. \& PRATT, B.R. 2000. A varied Middle Ordovician sponge spicule assemblage from Western Newfoundland. Journal of Paleontology 74(3), 386-393. 